УДК 316.6

DOI: https://doi.org/10.33120/ssj.vi46(49).163

\author{
Хоржевська Інна Михайлівна \\ кандидат психологічних наук, доцент кафедри психології. \\ Чорноморський національний університет імені Петра Могили, \\ м. Миколаїв, Україна \\ ORCID ID 0000-0002-5497-2812 \\ innahorzhevska@gmail.com
}

\title{
СОЦІАЛНО-ПСИХОЛОГІЧНІ ОСОБЛИВОСТІ ОБРАЗУ МАЙБУТНЬОГО У ВАГІТНИХ ЖІНОК З РІЗНИМ РІВНЕМ САМОЗВИНУВАЧЕННЯ
}

\begin{abstract}
Метою дослідження було з'ясувати соціально-психологічні особливості образу майбутнього у вагітних жінок з переважанням самозвинувачувальних реакцій. Методологічну основу дослідження склали гендерний підхід у психології, а також наукові напрацювання щодо психосоматичного впливу негативних емоційних станів на здоров'я вагітних. Показано, що соціально-психологічні особливості образу майбутнього (зокрема, антиципація подальших сімейних стосунків, майбутня материнська ідентичність, прагнення відповідати гендерним ролям дружини і матері) регулюють емоційні стани вагітної. Тенденції самозвинувачення розглянуто як елемент гендерної ролі жінки i матері, що перешкоджає формуванню нормальної материнської ідентичності та оптимістичного образу майбутнього. Визначено відмінності між жінками з високим і низьким рівнем самозвинувачення в таких соціальнопсихологічних характеристиках образу майбутнього: прийняття себе в часовій перспективі; материнська ідентичність; стереотипність образу майбутнього i прагнення відповідати гендерним приписам. Виявлено також взаємозв'язок між схильністю до самозвинувачень у ситуації фрустрації і прагненням відповідати гендерній ролі. Зауважено, що інтрапунітивність реакцій корелює також із ситуативною тривожністю, мінливістю фрустраційних реакцій та емоційним забарвленням образу майбутнього. Рамки дослідження задано можливістю обстеження вагітних лише на першому i другому триместрі вагітності. Результати дослідження можна використати в просвітницькій роботі фахівців з гендерної педагогіки, зокрема в підготовці молодих жінок до материнства. Як напрям подальших досліджень визначено вивчення конструктивної і деструктивної ролі перцепції різних елементів жіночих (фемінних) гендерних ролей в успішності регуляції репродуктивної поведінки за допомогою образу майбутнього.
\end{abstract}

Ключові слова: образ майбутнього; соціально-психологічні особливості образу майбутнього; інтрапунітивні реакції; гендерна роль; репродуктивна поведінка.

\section{SOCIO-PSYCHOLOGICAL PECULIARITIES OF THE FUTURE'S IMAGE OF PREGNANT WOMEN WITH DIFFERENT LEVEL OF SELF-BLAMING}

\author{
Inna M. Khorzhevska \\ Ph.D. in Psychology, Docent at the Department of Psychology, \\ Petro Mohyla Black See National University, \\ Mykolayiv, Ukraine \\ ORCID ID 0000-0002-5497-2812 \\ innahorzhevska@gmail.com
}

The aim of the study was to find out the socio-psychological peculiarities of the future's image in pregnant women with a dominance of self-blaming reactions. The methodological basis of the study was a gender approach in psychology, as well as scientific research on the psychosomatic 
impact of negative emotional states on the health of pregnant women. Socio-psychological features of the future's image (in particular, the anticipation of further family relations, future maternal identity, the desire to correspond to the gender roles of wife and mother) regulate the emotional state of the pregnant woman. Tendencies of self-blame are considered as an element of the gender role of women and mothers, which hinder the formation of a normal maternal identity and an optimistic image of the future. There are differences between women with high and low levels of self-blame in the following socio-psychological characteristics of the future's image: self-acceptance in the long time perspective; maternal identity; stereotyping of the future's image and the desire to comply with gender requirements. There is also a link between the self-blaming tendency in a situation of frustration and the desire to correspond to gender roles. It is noted that intrapunitiveness of reactions also correlates with situational anxiety, the variability of frustration reactions, and emotional coloring of the future's image. The scope of the study was set by the possibility of examining pregnant women only in the first and second trimesters of pregnancy. The results of the study can be used in the educational work of specialists in gender pedagogy, aimed at preparing young women for motherhood. The direction of further research is to study the constructive and destructive role of various elements' perception of female (feminine) gender roles in the success of the reproductive behavior regulation through the future's image.

Keywords: future's image; socio-psychological features of the future's image; intrapunitive reactions; gender role; reproductive behavior.

Постановка проблеми. Образ майбутнього вагітної жінки $\epsilon$ елементом самопрограмування, що впливає як на успішність процесу виношування та пологів, так і на подальші стосунки породіллі 3 дитиною і сім'єю загалом. Його соціально-психологічні особливості (зокрема, візія подальших сімейних стосунків, майбутня материнська ідентичність, прагнення відповідати гендерним ролям дружини та матері) регулюють поведінку вагітної, іiі емоційні стани, зумовлюють гармонійне (органічне, не-стресове) прийняття дитини у своє життя.

Тенденції самозвинувачення (які актуалізуються у фрустраційних ситуаціях або при спогадах про них) ми розглядаємо не лише як індивідуальну рису, а і як елемент гендерної ролі жінки та матері, який часто прищеплюється соціумом у процесі гендерної соціалізації. Вони перешкоджають формуванню нормальної материнської ідентичності та образу щасливого майбутнього. Схильність до осуду власних дій, інтрапунітивних реакцій спричиняють атитюд “я недостойна", що позначається на соціально-психологічних особливостях образу майбутнього. Оскільки в процесі вагітності жінка є особливо вразливою до різних психосоматичних впливів, це може позначатися на перебігу вагітності, ускладнювати його.

Аналіз останніх досліджень і публікацій, виокремлення нерозв'язаних частин загальної проблеми. Образ майбутнього розглядається в психології як структурний елемент психологічного часу особистості, який являє собою узагальнену візуалізацію моделі іiі власного майбутнього, що є результатом його антиципації (близької, середньої і віддаленої перспективи). Його основними функціями $є$ конструювання майбутнього і концептуалізація часової перспективи власного життя. Тому образ майбутнього часто стає регулятором сьогоденної поведінки: ми обираємо певний спосіб дій, власне, щоб досягти конкретного майбутнього. 3 огляду на це можемо припустити, що образ майбутнього $є$ також важливим регулятором репродуктивної поведінки жінки: планування сім'ї, виношування і народження дитини.

Гендерна соціалізація накладає істотний відбиток на Я-образ жінки. У процесі соціалізації особистість засвоює гендерні схеми, ролі та експектації соціуму щодо поведінки типового чоловіка/жінки. Статево-рольові стереотипи та гендерні схеми зумовлюють особливості соціальної та рольової перцепції особистості, характеристики інтеракції та сприймання нею власної життєвої перспективи (Вет, 1983; Плетка, 2013). Типові жіночі (фемінні) ролі, такі як бабця, мати, дружина тощо, передбачають як конструктивні, так і деструктивні рольові приписи. Водночас регламентованість фемінних ролей у багатьох 
суспільствах є вищою, ніж маскулінних. Л. Гридковець (2016), аналізуючи притаманні традиційному українському суспільству вимоги до жінки, зосереджує увагу на двох основних критеріях вартісності дівчини/жінки: 1) іiі здатність вийти заміж; 2) їі здатність народити дітей. Обидва критерії стосуються репродуктивної поведінки, яка була важливою для продовження роду. Тому будь-яка фізична вада сприймалася як вирок; і хоча дівчина не була в цьому винною, вона фактично потрапляла в ситуацію обвинувачення.

Не дивно, що тенденції самозвинувачення притаманні багатьом жінкам. Вони можуть виявлятися в різних ситуаціях, але найбільше актуалізуються в ситуації фрустрації. Інтеріоризуючи як екстрапунітивну, так і інтрапунітивну поведінку своєї матері, жінка звинувачує й засуджує себе передусім у репродуктивно значущих ситуаціях. Але почуття провини $є$ одним 3 найбільш деструктивних щодо людського здоров'я. Почуття провини вимагає покарання, й організм інтуїтивно та ірраціонально “створює” ситуацію, яка могла б служити “покаранням”. Передусім це стосується вагітних жінок, які є особливо вразливими до психосоматичних впливів (Ponirakis et al., 1998). Це може бути поведінка, що погіршує стан організму. Різноманітні ускладнення перебігу вагітності можуть бути наслідком такої поведінки.

Метою статті $є$ 3'ясування соціально-психологічних особливостей образу майбутнього у вагітних жінок з переважанням інтрапунітивних (самозвинувачувальних) реакцій.

Виклад основного матеріалу дослідження. Логіка нашого емпіричного дослідження зумовила послідовність його етапів:

- формування вибірки досліджуваних - вагітних жінок 3 нормальним i патологічним перебігом вагітності;

- добирання психодіагностичних методик для виявлення звинувачувальних тенденцій у вагітних та їх спрямованості, соціально-психологічних особливостей образу майбутнього у вагітних жінок.

- виявлення взаємозв'язку соціально-психологічних особливостей образу майбутнього у вагітних жінок з тенденціями самозвинувачення;

- визначення відмінностей в образі майбутнього між жінками з високим і низьким рівнем самозвинувачення.

Вибірку досліджуваних склала 51 жінка віком від 23 до 35 років на першому i другому триместрах вагітності як з нормальним перебігом вагітності, так і з відхиленнями від норми (зокрема, із загрозою викидня). Психологічне обстеження вагітних проводилося при жіночій консультації одного 3 пологових будинків м. Миколаєва. Кожна 3 вагітних стояла на обліку в жіночій консультації і періодично зверталася туди для консультації 3 акушером-гінекологом.

Відповідно, серед обстежених вагітних жінок 30 мали нормальний перебіг вагітності, a 21 - загрозу викидня; 28 осіб були на першому і 23 - на другому триместрі вагітності; 32 обстежені жінки не мали досвіду материнства і чекали первістка.

Для психологічної діагностики вагітних було застосовано:

1) тест фрустраційних реакцій Розенцвейга - для виявлення тенденцій самозвинувачення; за його результатами з вибірки діагностованих було виокремлено жінок зі схильністю до самозвинувачення;

2) тест тривожності Спілбергера - Ханіна - для отримання додаткової інформації щодо типових для вагітних емоційних переживань страху та тривоги;

3) футуристичний наратив;

4) контент-аналіз для обробки отриманих наративів діагностованих.

Цей інструментарій дав змогу визначити образ майбутнього у досліджуваних вагітних та його соціально-психологічні особливості.

Розгляньмо детальніше методи і методики нашого дослідження.

Тест фрустраційних реакцій Розенцвейга призначений для діагностики особливостей поведінки особи в ситуаціях фрустрації. Він дає змогу визначити характер вербального 
реагування на складнощі, оцінити дії суб'єкта за рівнем конструктивності (критерієм якої є, зокрема, наявність звинувачень та їхня спрямованість). Кожна відповідь оцінюється за двома ключовими позиціями: 1) висловленою досліджуваним спрямованістю реакції: a) екстрапунітивною, тобто звинуваченнями, спрямованими назовні; б) інтрапунітивною (самозвинувачувальною); в) імпунітивною (ухиляння від приписування відповідальності або вини кому б то не було) і 2) вираженим досліджуваним типом реакції: а) перешкоднодомінантною; б) его-захисною і в) необхіднісно-адаптивною (відповідь спрямована на певне прийняття фрустраційної ситуаціі).

Під час обробки результатів здійснюється також аналіз тенденцій, бо суб'єкт час від часу змінює свою поведінку, переходячи від одного типу реакції до іншого (наприклад, від імпунітивного до інтрапунітивного).

Одним з інструментів дослідження образу майбутнього є методика футуристичного наративу. Досліджуваним жінкам давалося завдання описати своє щасливе сімейне майбутнє 8-12 реченнями.

Зазвичай зміст таких творів-наративів дає змогу вивчити певні параметри образу майбутнього, серед яких:

- ставлення до майбутнього, його емоційна оцінка (оптимістична, песимістична, нейтральна; незважаючи на інструкцію, деякі жінки уявляють собі проблемне, емоційноамбівалентне майбутнє);

- часова перспектива, яка конкретизує життєве завдання в часі (невизначена, близька, віддалена, перспектива всього життя);

- деталізованість картини майбутнього як чіткість його бачення (висока, середня та низька);

- цілісність бачення життя, що презентується поєднанням у наративі минулого, теперішнього i майбутнього (транспектива може бути яскраво вираженою, слабко вираженою і невираженою) і т. ін.

У нашому дослідженні категоріями контент-аналізу були: 1) візія стосунків у сім’ї, 2) майбутня материнська ідентичність, 3) прагнення відповідати гендерним ролям дружини та матері, 4) стереотипність образу майбутнього (відповідність зразкам); 5) емоційне забарвлення образу майбутнього (позитивне, негативне, нейтральне, амбівалентне).

Психологічна діагностика тривожності та екстра- або інтрапунітивних реакцій опитаних виявила певні тенденції. Так, обстеження вагітних за тестом Розенцвейга показало, що загалом по вибірці є незначне переважання екстрапунітивних фрустраційних реакцій. Це означає, що в ситуаціях фрустрації жінкам властиво звинувачувати оточення та обставини, а не себе. Іншим діагностованим більше притаманні інтрапунітивні реакції, що виявляються у схильності до самозвинувачень, почутті провини. Імпунітивних реакцій загалом виявилося небагато.

Оскільки до вибірки увійшли жінки як з нормальним, так і з ускладненим перебігом вагітності, ми порівняли ї за параметром схильності до самозвинувачення. Значущість відмінностей, підрахована за Н-критерієм Краскела - Уолліса, становить 10,7 при p=0,039. Отже, жінки, які мають загрозу викидня, частіше вдаються до інтрапунітивних реакцій (табл. 1).

Таблиия 1

Результати обстеження за тестом фрустраційних реакцій С. Розенцвейга (у \%)

\begin{tabular}{|l|c|c|c|}
\hline \multicolumn{1}{|c|}{ Категорії обстежуваних } & $\begin{array}{c}\text { Екстрапунітивні } \\
\text { реакції }\end{array}$ & $\begin{array}{c}\text { Інтрапунітивні } \\
\text { реакції }\end{array}$ & $\begin{array}{c}\text { Імпунітивні } \\
\text { реакції }\end{array}$ \\
\hline $\begin{array}{l}\text { Жінки з ускладненим перебігом } \\
\text { вагітності (із загрозою викидня) }\end{array}$ & 49 & 48 & 3 \\
\hline $\begin{array}{l}\text { Вагітні з нормальним перебігом } \\
\text { вагітності }\end{array}$ & 45 & 34 & 21 \\
\hline
\end{tabular}


Аналіз тенденцій засвідчив, що близько третини всіх вагітних мають схильність до зміни своїх фрустраційних реакцій у процесі виконання завдань методики. В основному це були вагітні із загрозою викидня під час першого триместру вагітності. Аналогічні показники більшості жінок з нормальним перебігом вагітності є досить стійкими.

Високий рівень тривожності, згідно з результатами тесту Спілбергера - Ханіна, частіше спостерігається у жінок з вираженими інтрапунітивними реакціями. Як видно 3 таблиці 2, тривожні стани найчастіше переживаються в першому триместрі. Це можна пояснити його специфікою: тривожні стани пов'язані з встановленням факту вагітності і прийняттям ризиків, наявних у цій ситуації. Водночас бачимо, що високий рівень тривожності більшою мірою притаманний вагітним жінкам з переважанням інтрапунітивних реакцій як у першому, так і в другому триместрі (табл. 2).

Табличя 2

Розподіл показників високого рівня ситуативної тривожності (за даними тесту Спілбергера - Ханіна) у вагітних жінок (у \%)

\begin{tabular}{|l|c|c|c|}
\hline \multicolumn{1}{|l|}{ Періоди } & $\begin{array}{c}\text { Усі вагітні } \\
\text { жінки }\end{array}$ & $\begin{array}{c}\text { Вагітні з переважанням } \\
\text { інтрапунітивнихреакцій }\end{array}$ & $\begin{array}{c}\text { Вагітні з переважанням імпунітивних } \\
\text { і екстрапунітивних реакцій }\end{array}$ \\
\hline $\begin{array}{l}\text { Перший } \\
\text { триместр }\end{array}$ & 67 & 38 & 29 \\
\hline $\begin{array}{l}\text { Другий } \\
\text { триместр }\end{array}$ & 48 & 31 & 17 \\
\hline
\end{tabular}

Наративні тексти, за допомогою яких жінки змальовували образ свого майбутнього, продемонстрували їхнє позитивне ставлення до вагітності і до майбутньої дитини. А проте роль матері є непропрацьованою у більшості вагітних й описана схематично, нереалістично, 3 орієнтацію на соціально бажані зразки.

Питома вага категорії “Прийняття себе в часовій перспективі” («Самоприйняття») є значно нижчою у жінок із тенденцією самозвинувачення. Такі результати логічно узгоджуються з показником питомої ваги категорії "Стереотипність образу майбутнього" $(\mathrm{H}=18,01 \mathrm{p}=0,033)$. Цей показник $є$ значно вищим саме у вагітних жінок із тенденцією до самозвинувачення. Образ щасливого майбутнього у деяких з них виглядає як "рекламна картинка" і є досить схематичним. Це можна пояснити скутістю в мріях, зумовленою латентним почуттям провини. Прикметно також, що в таких стереотипних образах майбутнього жінка жорстко дотримується меж своєї гендерної ролі (наприклад, “я завжди займаюся дитиною і господарством, а чоловік заробляє гроші»).

Розгляньмо відтак результати контент-аналізу наративних текстів діагностованих вагітних жінок (підраховувалася питома вага категорій) (рис.).

Статистично значущі відмінності між вагітними жінками з високим і низьким рівнями самозвинувачення встановлено щодо таких соціально-психологічних особливостей образу майбутнього:

- прийняття ролі матері $(\mathrm{H}=9,23$ при $\mathrm{p}=0,05)$;

- $\quad$ самоприйняття $(\mathrm{H}=21,41$ при $\mathrm{p}=0,03)$;

- прагнення відповідати гендерним ролям дружини і матері $(\mathrm{H}=7,81$ при $\mathrm{p}=0,05)$.

Найбільшою $\epsilon$ різниця між діагностованими 3 високим i низьким рівнями самозвинувачення у самоприйнятті. Переживання почуття провини заважає жінці прийняти себе такою, якою вона є. Але не зовсім очевидним $\epsilon$ те, що низьке самоприйняття разом зі самозвинуваченням перешкоджає прийняттю вагітною жінкою ролі матері. Можна інтерпретувати це як формування під впливом самозвинувачень латентного атитюду “Я недостойна" (недостойна бути матір'ю, мати щасливу сім’ю і т. ін.) Переживання такої диспозиції перешкоджає релаксації, знижує рівень домагань, не дає змоги відчути спектр можливостей, які відкриває материнство.

Прагнення відповідати гендерним приписам щодо ролей жінки і матері $є$ більш вираженим у жінок з високим рівнем самозвинувачення. Завищена цінність цих приписів 
(зокрема й значення щасливого сімейного життя) ускладнює тенденції самозвинувачення, якщо не вдається досягти бажаних “показників”.

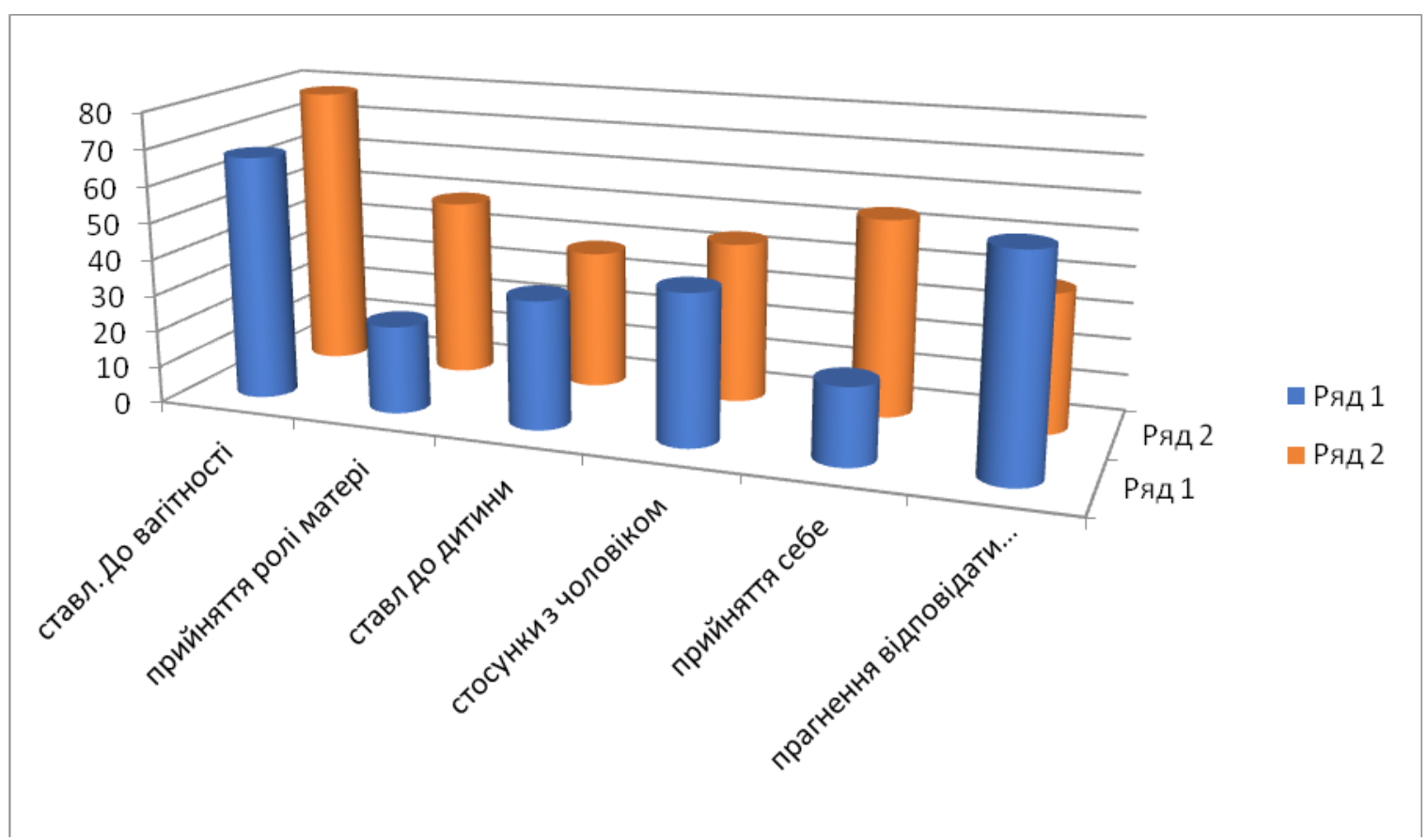

Puc. Результати контент-аналізу наративів діагностованих (ряд 1 - вагітні з високим рівнем самозвинувачення; ряд 2 - вагітні з низьким рівнем самозвинувачення)

I, нарешті, показники загального емоційного забарвлення образу майбутнього також дали несподіваний результат: не всі діагностовані дотримувалися інструкції, хоча вона програмувала їх уявити образ позитивного, щасливого майбутнього (табл. 3).

Кореляційний аналіз засвідчив також наявність взаємозв'язку між такими параметрами:

- ситуативна тривожність та інтрапунітивність фрустраційних реакцій $(\mathrm{r}=0,43)$;

- ситуативна тривожність і переважання зміни тенденцій у фрустраційних реакціях, тобто специфічна нестійкість реакцій такого роду $(\mathrm{r}=0,35)$;

- самоприйняття і прийняття ролі матері $(\mathrm{r}=0,51)$;

- низьке самоприйняття і емоційна амбівалентність образу майбутнього $(\mathrm{r}=0,32)$.

\section{Кореляційні зв'язки самозвинувачувальних реакцій} з особливостями образу майбутнього (r)

\begin{tabular}{|l|c|c|}
\hline \multicolumn{1}{|c|}{ Категорії обстежуваних } & $\begin{array}{c}\text { Прагнення відповідати } \\
\text { гендерним рольовим приписам }\end{array}$ & $\begin{array}{c}\text { Стереотипність образу } \\
\text { майбутнього }\end{array}$ \\
\hline Жінки з інтрапунітивними реакціями & 0,38 & $-0,32$ \\
\hline $\begin{array}{l}\text { Жінки з екстрапунітивними та } \\
\text { імпунітивними реакціями }\end{array}$ & 0,26 & 0,08 \\
\hline
\end{tabular}

Схильність до самозвинувачення в ситуаціях фрустрації є досить руйнівною сама по собі, але вона, крім того, ще й поєднується 3 підвищеною тривожністю. Напруженість породжує потенційний страх, що ситуація вийде з-під контролю. А тривога, відповідно, зумовлює невпевненість у правильності своїх реакцій на зовнішні чинники фрустрації, що іноді посилює готовність змінювати ці реакції. Звідси нестійкість і мінливість поведінки.

Практична значущість дослідження полягає в доцільності застосування його результатів як у консультативній практиці психологів, так i в просвітницькій роботі 
педагогів, спрямованій на підготовку молодих жінок до материнства. Елементом змісту цієї роботи мали б бути усвідомлення і регуляція деструктивних тенденцій самозвинувачення.

Висновки та перспективи подальших досліджень. 3'ясовано відмінності між жінками 3 високим i низьким рівнями самозвинувачення щодо таких соціальнопсихологічних характеристик образу майбутнього: прийняття себе в часовій перспективі; материнська ідентичність; стереотипність образу майбутнього і прагнення відповідати гендерним приписам. Виявлено також взаємозв'язок між схильністю до самозвинувачень у ситуації фрустрації і прагненням відповідати гендерній ролі. Інтрапунітивність реакцій корелює також із ситуативною тривожністю, мінливістю фрустраційних реакцій та емоційним забарвленням образу майбутнього. Перспективи подальших досліджень пов'язані зі з'ясуванням конструктивної і деструктивної ролі перцепції різних елементів жіночих (фемінних) гендерних ролей в регуляції репродуктивної поведінки за допомогою образу майбутнього. Видається доцільним означити ці перцептивні тенденції як у вагітних жінок, так і в їхніх чоловіків у контексті функціонування їхніх стосунків у подружньому та сімейному житті.

\section{Список використаних джерел}

Гридковець, Л. М. (2016). Світ життєвих криз людини як дитини своєї сім'ї, свого роду та народу. Львів: Скриня.

Плетка, О. Т. (2013). Прояви гендерної ідентичності у молоді при груповій роботі. Простір apm-терапії: досвід становлення. Матеріали X Ювілейної міжнар. міждисплін. наук-практ. конф. (м. Київ, 28 лютого, 1-2 березня 2013 р.) (с. 78-81). Київ: Золоті ворота.

Bem, S. (1983). Gender Schema Theory and Its Implications for Child Development. Journal of Women in Culture and Society, 8 (4), 598-615.

Ponirakis, A., Susman, E. J., \& Stifter, C. A. (1998). Negative emotionality and cortisol during adolescent pregnancy and its effects on infant health and autonomic nervous system reactivity. Development of Psychobiology, 33(2), 163-174.

\section{References}

Bem, S. (1983). Gender Schema Theory and Its Implications for Child Development. Journal of Women in Culture and Society, 8 (4), 598-615. (in English)

Hrydkovets, L. M. (2016). Svit zhyttievykh kryz liudyny yak dytyny svoiei simi, svoho rodu ta narodu [The world of life's krisis of a person as a child of her/his family, her/his clan and her/his nation]. Lviv: Skrynia. (in Ukrainian)

Pletka, O. T. (2013). Proiavy hendernoi identychnisti u molodi pry hrupovii roboti [Manifestations of gender identity in youth in group work]. Prostir art-terapii: dosvid stanovlennia. Materialy X Yuvileinoi mizhnarodnoi mizhdysplynarnoi naukovo-praktychnoi konferentsii (Kyiv, 28 lutoho, 1-2 bereznia 2013 r.) (pp. 78-81). Kyiv: Zoloti vorota. (in Ukrainian)

Ponirakis, A., Susman, E. J., \& Stifter, C. A. (1998). Negative emotionality and cortisol during adolescent pregnancy and its effects on infant health and autonomic nervous system reactivity. Development of Psychobiology, 33 (2), 163-174. (in English) 